\title{
Organic Acids Exuded From Roots Increase the Available Potassium Content in the Rhizosphere Soil: A Rhizobag Experiment in Nicotiana tabacum
}

\author{
Yongfeng Yang ${ }^{1}$ \\ College of Tobacco Science, Henan Agricultural University, Zhengzhou \\ 450002, Henan, China
}

Zhixiao Yang ${ }^{1}$ and Shizhou Yu Guizhou Academy of Tobacco Science, Guiyang 550081, Guizhou, China

Hongli Chen ${ }^{2}$

College of Tobacco Science, Henan Agricultural University, Zhengzhou 450002, Henan, China

Additional index words. root, soil potassium, organic acid, root vigor, stress-resistant enzyme activity

\begin{abstract}
Organic acid secretion from higher plant roots into the rhizosphere soil plays an important role in nutrient acquisition and metal detoxification; however, their precise functions and the related mechanisms in abiotic stress tolerance remain poorly understood. Tobacco is an important crop plant, so thoroughly elucidating these factors in tobacco is of high priority. In the present study, the activation effect on soil potassium (K), contents of exuded organic acids, and physiological changes in the roots of various tobacco varieties under both normal $K$ supply and $K$-deficiency stress were investigated. Our results showed that one high-K variety (ND202) exhibited a significantly higher total content of organic acids in the root exudates and the highest available $K$ content in the rhizosphere soil, compared with two common ones (K326 and NC89). Moreover, the high-K tobacco variety was less affected in terms of root vigor under K-deficiency stress, and displayed greater increases in the activities of the stress-resistant enzymes consisting of superoxide dismutase (SOD), peroxidase (POD), and catalase (CAT). Taken together, these results provide evidence that tobacco roots exude large amounts of organic acids to increase the available $K$ content in the rhizosphere soil and improve the utilization rate of soil $\mathbf{K}$.
\end{abstract}

Potassium $(\mathrm{K})$ is one of the major elements absorbed by plants and plays a critical role in plant growth, development, and physiological metabolism. Tobacco is known to be a K-favoring crop. Potassium is not only a crucial nutrient for tobacco, it also improves the flammability of tobacco leaves and so decreases the amount of tar produced during burning (Guo et al., 2002; Luo et al., 2000). Using larger amounts of $\mathrm{K}$ fertilizers and promoting the availability of $\mathrm{K}$ can increase $\mathrm{K}$ content in tobacco leaves (Wang et al., 2014); however, in addition to increasing costs, the extensive use of fertilizers can destroy soil structures, decrease the amount

\footnotetext{
Received for publication 18 Sept. 2018. Accepted for publication 19 Nov. 2018

This work was financially supported by the Key Program of Henan Tobacco Industry Co., Ltd. (ZW2014003).

${ }^{1}$ These two authors contributed equally to this paper.

${ }^{2}$ Corresponding author. E-mail: linyingxian2006@ 163.com.
}

of organic matter in the soil, and aggravate environmental pollution (Furoc-Paelmo et al., 2012). Therefore, an alternative to chemical $\mathrm{K}$ fertilizer is necessary for the sustainable development of agriculture.

One possible alternative could be to fully exploit the reservoir of $\mathrm{K}$ in the soil. Soil has rich reserves of $\mathrm{K}$, among which only $1 \%$ to $2 \%$ can be directly absorbed by plants (Zhang et al., 2014); however, the acidification and dissolution of soil $\mathrm{K}$ are prevented in calcareous soil due to the high $\mathrm{pH}$ and calcium content (Yang and Peng, 2006). It may be more economically viable to transform the fixed slow-release $\mathrm{K}$ into readily available $\mathrm{K}$ that can be absorbed by plants. It is hypothesized that malate release results in the building up of malate levels in the rhizosphere soil, where it increases the available K content (Shi et al., 2011). Cluster roots are characterized to release organic acid anions at a high level, and citrate is demonstrated to be the predominant acid released by cluster roots of tobacco under a K-deficient condition (Wu et al., 2013). Collectively, tobacco roots will exude greater amounts of substances and thereby increase the available $\mathrm{K}$ content in the rhizosphere soil, which is a response of tobacco plants to improve their absorption and utilization of soil $\mathrm{K}$.

Recent studies on root exudates have mainly focused on species such as rice (Hao et al., 2010), maize (Ling et al., 2011), watermelon (Wu et al., 2008), and cucumber (Chen et al., 2011; Zhang et al., 2013). The previously identified components of root exudates include sugars, enzymes, amino acids, organic acids, phenolic acids, sterols, nucleotides, flavonoids, growth factors, and other substances (Sison et al., 2010). The root exudates have a significant influence on soil properties, the microbial community, and soil functions (Haichar et al., 2014). The exudation of organic acids, such as oxalate, citrate, malate, oxalate, succinate, and fumarate, by plant roots constitutes a response mechanism under different stress situations, which may be caused mainly by a nutritional deficiency (Carvalhais et al., 2011; Hoffland et al., 2006; Lipton et al., 1987; Mohan et al., 2015), the presence of a toxic element, or a lack of nutrition (Ae et al., 1990; Chiang et al., 2006; Gandner et al., 1983; Hoffland et al., 1989; Zeng et al., 2008).

The dissociation of mineral $\mathrm{K}$ from soil by organic acids is mainly achieved by organic complexes consisting of organic ligands that are capable of chelation of metal ions, which can accelerate the decomposition of minerals. The role of protons from organic acids lies in the dissolution of insoluble minerals and lattice substitution for K. Different types of organic acids exhibit varying capacities to decompose and release $\mathrm{K}$ from soil minerals (Cui et al., 2002; Melo et al., 2005). Research on the activation of mineral elements by tobacco root exudates has primarily focused on the effect of small molecule organic acids on $\mathrm{K}$ conversion in various types of soil and K-rich minerals (Cong et al., 2009; Jiang et al., 2012; Zörb et al., 2014). Tobacco plants grown under normal conditions are capable of activating soil phosphorus (P) and $\mathrm{K}$ minerals, showing minor differences among various varieties. Under $\mathrm{P}$ and $\mathrm{K}$ stress, tobacco root exudates show an improved capacity to activate soil minerals, and the differences among various varieties are increased. Moreover, there are differences among tobacco root exudates regarding nutrient use efficiency in the rhizosphere soil (Zhou et al., 2005). Research on tobacco root exudates has generally focused on their effects on tobacco seed germination, plant growth, and enzyme activities ( $\mathrm{Yu}$ et al., 2014); however, little information is available on the types and contents of tobacco root exudates.

In the present study, we have separated the functional groups of organic acids into hydrogen ions and organic ligands to examine the chemical mechanism of soil $\mathrm{K}$ activation by major organic acids in root exudates. In addition, the types and total contents of organic acids in tobacco root exudates were determined, and the capacity 
of the root exudates to activate slowly available $\mathrm{K}$ in rhizosphere soil was compared among various varieties of tobacco. Furthermore, physiological changes in the roots were analyzed to identify the cause of the differences in the utilization rates of soil $\mathrm{K}$ among various tobacco varieties. This study will facilitate us to deeply understand the functions of organic acids in root exudates in the process of activating and using soil $\mathrm{K}$, and further explain the differences among various varieties, so as to provide theoretical basis for $\mathrm{K}$ nutrition and metabolism in plants, and breeding of high-K varieties.

\section{Materials and Methods}

Experimental design. Field trials were carried out in 2016 and 2017 at the scientific and educational park of Henan Agricultural University, respectively. The park is located in Zhengzhou in Henan Province, China, which is situated in the southern part of the North China Plain. The region exhibits a continental monsoon climate, within the North Temperate Zone. The average annual temperature is $14.2{ }^{\circ} \mathrm{C}$, the average annual rainfall is $640.9 \mathrm{~mm}$, and the $\geq 0{ }^{\circ} \mathrm{C}$ average annual cumulative temperature is $5178.8^{\circ} \mathrm{C}$. The clay soil in the experimental field contained (0-20 cm depth) $9.96 \mathrm{~g} \cdot \mathrm{kg}^{-1}$ organic matter, $0.95 \mathrm{~g} \cdot \mathrm{kg}^{-1}$ total nitrogen, $34.12 \mathrm{mg} \cdot \mathrm{kg}^{-1}$ available phosphorus, $79.91 \mathrm{mg} \cdot \mathrm{kg}^{-1}$ available $\mathrm{K}$, and $73.54 \mathrm{mg} \cdot \mathrm{kg}^{-1}$ available nitrogen.

The tobacco (Nicotiana tabacum L.) variety ND202 was used in this study. ND202 is a variety with high-K content more than $2.5 \%$ in leaves, which was bred by the College of Tobacco Science of Henan Agricultural University. Two common ones, including NC89 and $\mathrm{K} 326$, which are the main tobacco varieties with $\mathrm{K}$ content of $\approx 1.5 \%$ in northern China, were also chosen in our experiment. Two treatments were set according to the rate of $\mathrm{K}$ application: $\mathrm{K}_{1}$ (normal $\mathrm{K}$ supply) - N $0.13 \mathrm{~g} \cdot \mathrm{kg}^{-1}, \mathrm{P}_{2} \mathrm{O}_{5} 0.13 \mathrm{~g} \cdot \mathrm{kg}^{-1}$, and $\mathrm{K}_{2} \mathrm{O} 0.39$ $\mathrm{g} \cdot \mathrm{kg}^{-1}$; and $\mathrm{K}_{2}$ (K-deficiency stress) - N 0.13 $\mathrm{g} \cdot \mathrm{kg}^{-1}, \mathrm{P}_{2} \mathrm{O}_{5} 0.13 \mathrm{~g} \cdot \mathrm{kg}^{-1}$, and $\mathrm{K}_{2} \mathrm{O} 0 \mathrm{~g} \cdot \mathrm{kg}^{-1}$. Tobacco seedlings showing uniform growth (six to seven true leaves) were transplanted to plastic pots containing $10 \mathrm{~kg}$ of soil. Fertilization was performed three times, at transplantation, and 1 and 2 weeks after transplantation, at a dose $\mathrm{N}: \mathrm{P}_{2} \mathrm{O}_{5}: \mathrm{K}_{2} \mathrm{O}$ ratio of $2: 1: 1$. Other practices conformed to standard tobacco field management specification. The plants were cultivated using the rhizobag method. The rhizobags consisted of 300mesh nylon screen and were $15 \mathrm{~cm}$ long, 15 $\mathrm{cm}$ wide, and $20 \mathrm{~cm}$ high. Each bag was filled with $500 \mathrm{~g}$ of soil. The experiment adopted a randomized block design with a total of six treatment combinations and 50 pots per treatment. After $30 \mathrm{~d}$ of incubation, tobacco roots of three varieties with good growth consistency were collected entirely under two $\mathrm{K}$ application treatments, which were used for the determination of root vigor and stress-resistant enzyme activities. Measurements were replicated six times with three plants per treatment. The soil inside of rhizobags was removed from the nylon screen, dried in the air, and then used for $\mathrm{K}$ analysis and root exudate collection.

The reagents (analytical grade) used in the experiment to study the activation of organic acids on soil available $\mathrm{K}$ included oxalic acid (OA), citric acid (CA), sodium oxalate (OA$\mathrm{Na})$, sodium citrate $(\mathrm{CA}-\mathrm{Na})$, and hydrochloric acid $(\mathrm{HCl})$. The chemical properties of OA and CA are shown in Table 1. Three types of treatments were designed in this work: 1) acidification, with $\mathrm{HCl}$; 2) complex formation, with OA-Na and $\mathrm{CA}-\mathrm{Na}$; and 3) acidification + complex formation, with $\mathrm{OA}$ and $\mathrm{CA}$. The deionized water was used as control (CK). The concentration of each substance was set a $0.25 \mathrm{~mol} \cdot \mathrm{L}^{-1}$. The experiment included six treatments, with three replications in each treatment. The $\mathrm{pH}$ value of each reagent solution is provided in Table 2. Soil from the experimental field was ground and passed through a 20 -mesh screen. The soil was autoclaved three times through intermittent steaming at $120{ }^{\circ} \mathrm{C}$ and then dried at a low temperature to dryness. Soil samples $(50 \mathrm{~g})$ in conical flasks were weighed, followed by the addition of four types of solution until the soil water content reached $45 \%$. The soil samples and reagents were autoclaved to eliminate microbial interference, and chloroform was added to inhibit microbial activity. The flasks were placed in a thermostat incubator at $26^{\circ} \mathrm{C}$, and the soil moisture content was kept constant. Soil available K was determined at 1, 3, 7, 18, and $25 \mathrm{~d}$ of incubation.

Collection of root exudates. The roots of three tobacco varieties were washed to remove the rhizosphere soil at $30 \mathrm{~d}$ of incubation. The plants were incubated in $500 \mathrm{~mL}$ deionized water, and the water was changed and collected every $24 \mathrm{~h}$ for 3 consecutive days. The collected root exudates were loaded onto an XAD-4 resin column and eluted three times with $300 \mathrm{~mL}$ of methanol. The purified samples were concentrated to dryness using a rotary evaporator at $40{ }^{\circ} \mathrm{C}$ and then adjusted to a constant volume of $20 \mathrm{~mL}$ with ethanol. The root exudates were stored at $4{ }^{\circ} \mathrm{C}$ for further use.

Determination of organic acids exuded by the roots. The total content of organic acids was determined through improved spectrophotometry based on the principle that the carboxyl group reacts with the hydroxylamine group to form hydroximic acid in the DCC system, which further develops a color on reaction with ferric ions under acidic conditions (He et al., 2011). Generation of a standard curve for organic acids: Acetic acid standard solutions with different concentrations were formulated $\left(1 \times 10^{-3}, 2 \times 10^{-3}, 3 \times\right.$ $10^{-3}, 4 \times 10^{-3}$, and $\left.5 \times 10^{-3} \mathrm{~mol} \cdot \mathrm{L}^{-1}\right)$. One milliliter of the acetic acid standard solutions (using $1 \mathrm{~mL}$ of distilled water as a control) was added to test tubes, followed by the addition of $1 \mathrm{~mL}$ of a $0.08 \mathrm{~mol} \cdot \mathrm{L}^{-1}$ hydroxylamine hydrochloride solution and $1 \mathrm{~mL}$ of a $0.4 \mathrm{~mol} \cdot \mathrm{L}^{-1} \mathrm{DCC}$ ethanol solution. The mixture was completely mixed by shaking and then heated in a $50{ }^{\circ} \mathrm{C}$ water bath for $30 \mathrm{~min}$. Finally, $1 \mathrm{~mL}$ of a $0.7 \mathrm{~mol} \cdot \mathrm{L}^{-1} \mathrm{FeCl}_{3}$ solution was added, and the absorbance of the reaction solution at $520 \mathrm{~nm}$ was measured after complete reaction. The equation for calculating the standard curve was as follows: $Y=$ $101.3 X-0.0157$ (correlation coefficient $=$ 0.9996). A 2-mL aliquot of the root exudates stored at $4{ }^{\circ} \mathrm{C}$ was then added to the test tubes, and the absorbance of organic acids in the root exudates $(Y 1)$ was measured following the same procedure. Root exudation of organic acids $\left(\mathrm{g} \cdot \mathrm{L}^{-1}\right)=(Y 1+0.0157) \times 60 \times$ $0.02 /(101.3 \times 1)$.

Measurement of soil potassium content. Five grams of air-dried rhizosphere soil was passed through a 1-mm sieve. The sieved soil was added to a $100-\mathrm{mL}$ flask or a large test tube, followed by the addition of $50 \mathrm{~mL}$ of a 1 $\mathrm{g} \cdot \mathrm{mol}^{-1} \mathrm{NH}_{4} \mathrm{OAc}$ solution. The flask or test tube was then sealed with a rubber plug and oscillated for $30 \mathrm{~min}$, after which the solution was filtered through dry, ordinary qualitative filter paper. Soil available K and slowly available $\mathrm{K}$ contents were determined via flame photometry (Williams and Twine, 1960).

Assay of reducing capacity and stressresistant enzyme activities in the roots. After $30 \mathrm{~d}$ of incubation, the roots of various tobacco varieties were washed to remove the rhizosphere soil and then used to measure the reducing capacity and stress-resistant enzyme activities of the root system (Cui et al., 2015). The reducing capacity of the roots was analyzed using the triphenyl tetrazolium chloride method (Ryssov-Nielson, 1975). Superoxide dismutase (SOD) activity was measured via the nitro blue tetrazolium method. Peroxidase (POD) activity was measured with the guaiacol method. Catalase (CAT) activity was measured via ultraviolet absorption (Garcia-Limones et al., 2002).

Statistical analysis. For each measurement, the means from six replicates were calculated and the variance analysis was statistically analyzed using one-way analysis

Table 1. Chemical properties of the organic acids used in the experiment.

\begin{tabular}{|c|c|c|c|c|c|c|}
\hline \multirow[b]{2}{*}{ Organic acid } & \multirow[b]{2}{*}{ Structural formula } & \multirow[b]{2}{*}{ Group form } & \multicolumn{3}{|c|}{ Acid dissociation constant } & \multirow{2}{*}{$\begin{array}{l}\text { Stability coefficient of } \mathrm{Al} \\
\text { ion complex formation }\end{array}$} \\
\hline & & & $\mathrm{pK} 1$ & $\mathrm{pK} 2$ & $\mathrm{pK} 3$ & \\
\hline Oxalic acid & $\mathrm{HOOC}-\mathrm{COOH}$ & $\mathrm{H}_{2} \mathrm{~L}$ & 1.23 & 4.19 & - & 6.16 \\
\hline Citric acid & $\mathrm{HOOCCH}_{2} \mathrm{C}(\mathrm{OH})(\mathrm{COOH}) \mathrm{CH}_{2} \mathrm{COOH}$ & $\mathrm{H}_{3} \mathrm{~L}$ & 3.14 & 4.77 & 6.39 & 7.98 \\
\hline
\end{tabular}


of variance with SPSS 17.0 (SPSS Inc., Chicago, IL); moreover, the differences in the means between different treatments were separated by the least significance difference test at the $0.05 P$ level.

\section{Results}

Activation of organic acids on soil available $K$ content. The soil activation capacity varies with different types of organic acids in root exudates, and for the same type of organic acids, its activation capacity changes with the treatment time. In addition, the activation capacity of organic acids on soil $\mathrm{K}$ includes two aspects: acidification and complex formation. When an organic acid solution is added into soil, both reactions simultaneously exert an activation effect on soil $\mathrm{K}$.

The experimental results (Table 3) show that the coexistence acidification and complex formation significantly increased the soil available $\mathrm{K}$ content, and this effect was greater than that of individual acidification or complex formation. In the initial stage of the experiment, the effect on soil available $\mathrm{K}$ depended on the soil $\mathrm{pH}$, regardless of whether an organic acid, inorganic acid, or organic acid salt solution was used. Due to its strong alkalinity of the CA-Na solution, the soil available $\mathrm{K}$ content was even lower in this treatment compared with $\mathrm{CK}$ at the beginning of the reaction. With an increasing

Table 2. $\mathrm{pH}$ value of each reagent at $25^{\circ} \mathrm{C}$.

\begin{tabular}{lc}
\hline Reagent & $\mathrm{pH}$ \\
\hline $\mathrm{OA}$ & 1.03 \\
$\mathrm{CA}$ & 1.79 \\
$\mathrm{OA}-\mathrm{Na}$ & 8.21 \\
$\mathrm{CA}-\mathrm{Na}$ & 8.55 \\
$\mathrm{HCl}$ & 0.69 \\
$\mathrm{CK}$ & 7.12 \\
\hline
\end{tabular}

$\mathrm{CA}=$ citric acid; $\mathrm{CA}-\mathrm{Na}=$ sodium citrate; $\mathrm{CK}=$ control; $\mathrm{HCl}=$ hydrochloric acid; $\mathrm{OA}=$ oxalic acid; $\mathrm{OA}-\mathrm{Na}=$ sodium oxalate

Table 3. Soil available potassium content under different organic acid treatments $\left(\mathrm{mg}^{\mathrm{kg}} \mathrm{kg}^{-1}\right)$.

\begin{tabular}{lrrrrr}
\hline & \multicolumn{5}{c}{ Incubation time } \\
\cline { 2 - 6 } Treatment & \multicolumn{1}{c}{$1 \mathrm{~d}$} & $3 \mathrm{~d}$ & \multicolumn{1}{c}{$18 \mathrm{~d}$} & $18 \mathrm{~d}$ \\
\hline $\mathrm{OA}$ & $123.43 \mathrm{a}$ & $134.77 \mathrm{a}$ & $141.46 \mathrm{a}$ & $146.22 \mathrm{a}$ & $157.65 \mathrm{a}$ \\
$\mathrm{CA}$ & $97.21 \mathrm{~b}$ & $115.40 \mathrm{~b}$ & $114.24 \mathrm{~b}$ & $120.56 \mathrm{~b}$ & $122.03 \mathrm{~b}$ \\
OA-Na & $90.68 \mathrm{c}$ & $91.94 \mathrm{c}$ & $94.09 \mathrm{~d}$ & $97.84 \mathrm{c}$ & $99.53 \mathrm{~d}$ \\
$\mathrm{CA}-\mathrm{Na}$ & $81.08 \mathrm{~d}$ & $91.00 \mathrm{~cd}$ & $89.99 \mathrm{e}$ & $92.35 \mathrm{~d}$ & $98.49 \mathrm{~d}$ \\
$\mathrm{HCl}$ & $89.64 \mathrm{c}$ & $95.57 \mathrm{c}$ & $100.52 \mathrm{c}$ & $103.48 \mathrm{c}$ & $109.61 \mathrm{c}$ \\
$\mathrm{CK}$ & $84.66 \mathrm{~d}$ & $86.22 \mathrm{~d}$ & $90.81 \mathrm{e}$ & $94.52 \mathrm{~d}$ & $98.36 \mathrm{~d}$ \\
\hline
\end{tabular}

Different lowercase letters in the same column indicate significant differences at $P \leq 0.05$.

$\mathrm{CA}=$ citric acid; $\mathrm{CA}-\mathrm{Na}=$ sodium citrate $\mathrm{CK}=$ control $\mathrm{HCl}=$ hydrochloric acid; $\mathrm{OA}=$ oxalic acid; $\mathrm{OA}-$ $\mathrm{Na}=$ sodium oxalate

Table 4. Potassium content of different forms in the rhizosphere soil in different tobacco varieties under two $\mathrm{K}$ application treatments $\left(\mathrm{mg} \cdot \mathrm{kg}^{-1}\right)$.

\begin{tabular}{|c|c|c|c|c|}
\hline \multirow[b]{2}{*}{ Variety } & \multicolumn{2}{|l|}{$\mathrm{K}_{1}$} & \multicolumn{2}{|l|}{$\mathrm{K}_{2}$} \\
\hline & Slowly available $\mathrm{K}$ & Available K & Slowly available $\mathrm{K}$ & Available K \\
\hline ND202 & $703.78 \mathrm{c}$ & $476.1 \mathrm{a}$ & $684.67 \mathrm{c}$ & $70.45 \mathrm{a}$ \\
\hline NC89 & $837.63 \mathrm{~b}$ & $216.74 \mathrm{c}$ & $773.21 \mathrm{~b}$ & $60.41 \mathrm{~b}$ \\
\hline K326 & $888.67 \mathrm{a}$ & $316.3 \mathrm{~b}$ & $791.62 \mathrm{a}$ & $59.58 \mathrm{~b}$ \\
\hline
\end{tabular}

Different lowercase letters in the same column indicate significant differences at $P \leq 0.05$.

$\mathrm{K}_{1}=$ normal $\mathrm{K}$ supply; $\mathrm{K}_{2}=\mathrm{K}$-deficiency stress. but the content of available $\mathrm{K}$ that could be absorbed and used by plants shows significant differences under different treatment conditions. The contents of both slowly available $\mathrm{K}$ and available $\mathrm{K}$ were substantially higher under normal $\mathrm{K}$ application compared with those measured under $\mathrm{K}$ deficiency stress. Under K-deficiency stress, the $\mathrm{K}$ content in the rhizosphere soil was highest for ND202, whereas the values were much lower for NC89 and K326. This result indicated that ND202 could maintain a relatively high absorbable and available $\mathrm{K}$ content in the rhizosphere soil and, thus, ensured the absorption and utilization of $\mathrm{K}$ during normal growth of the plants.

Figure 1 shows that under K-deficiency stress, the total content of organic acids in the root exudates remained higher than under normal $\mathrm{K}$ treatment for all three tobacco varieties. In both the $\mathrm{K}_{1}$ and $\mathrm{K}_{2}$ treatments, ND202 exhibited a higher total content of organic acids in the root exudates compared with NC89 and K326, and these differences were significant. This result indicated that ND202 could exude more organic acids than NC89 and K326 through roots. This is an important reason why the root exudates of ND202 showed a higher capacity to activate soil $\mathrm{K}$ and resulted in a higher available $\mathrm{K}$ content in the rhizosphere soil.

Comparison of root vigor among various tobacco varieties. Root vigor is an important indicator reflecting the nutrient absorption, transformation, and translocation capacities of roots (Feldman, 1984). The level of root vigor directly affects the absorption of water and nutrients, thereby influencing the assimilation, conversion, or synthesis of material. Tobacco subjected to organic acid treatment shows a significantly greater root volume, dry weight, and activity than when organic acid treatment is not performed. This finding suggests that organic acids can markedly increase the growth of the tobacco root system and thereby contribute to the root absorption of nutrients (Qian et al., 1998).

In Table 5, NC89 and K326 exhibited lower root vigor than ND202 under both the $\mathrm{K}_{1}$ and $\mathrm{K}_{2}$ treatments. Meanwhile, NC89 and K326 displayed greater reductions in root vigor compared with ND202 that were not subjected to $\mathrm{K}$ application. This result showed that ND202 was less affected than NC89 and K326 by K-deficiency stress in terms of root vigor.

Comparison of antioxidant enzyme activity in the roots among various tobacco varieties. K-deficiency stress can result in reactive oxygen species (ROS) generation. To avoid or mitigate the damage caused by ROS, plants have developed various defense mechanisms, such as antioxidant enzymes, which are essential for maintaining the normal physiological and biochemical functions of plant cells under adverse stress (Liu et al., 2018; Qu et al., 2012). SOD reflects the ability of plants to eliminate ROS and resist the adverse situation. As one of the enzymes in the enzymatic defense system that protects against membrane lipid peroxidation, POD 
mainly plays a role in the enzymatic degradation of $\mathrm{H}_{2} \mathrm{O}_{2}$ to avoid peroxidation damage to cells. CAT is an important ROS-scavenging enzyme that catalyzes the decomposition of $\mathrm{H}_{2} \mathrm{O}_{2}$ into nontoxic $\mathrm{O}_{2}$ and $\mathrm{H}_{2} \mathrm{O}$, thus preventing the accumulation of $\mathrm{O}^{-}$and $\mathrm{H}_{2} \mathrm{O}_{2}$. Moreover, CAT acts as a key enzyme in the scavenging of ROS in plants (Meng et al., 2017).

Table 6 indicates that under normal $\mathrm{K}$ treatment, SOD and POD activities were higher, whereas CAT activity was lower for K326 and NC89 plants compared with ND202. Under K-deficiency stress, SOD activity was significantly higher for K326 and NC89 compared with ND202, whereas POD activity exhibited no significant differences among the various varieties, and CAT activity was significantly higher for ND202 resistant enzyme activities were increased in all three varieties under K-deficiency treatment compared with normal $\mathrm{K}$ treatment. ND202 exhibited the greatest increase in SOD, POD, and CAT activities, showing highly significant differences from the other

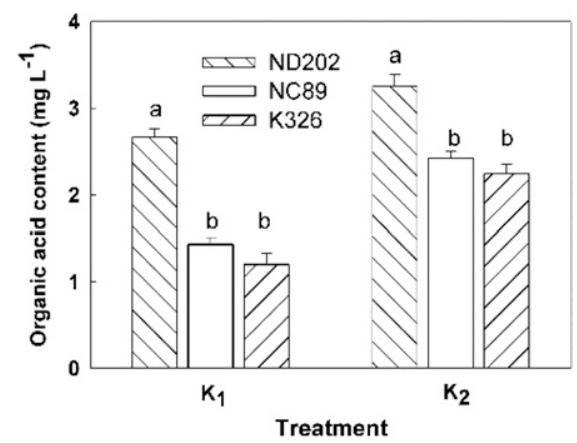

Fig. 1. Organic acid contents in different tobacco varieties under two $\mathrm{K}$ application treatments (mg. $\left.\mathrm{L}^{-1}\right) \cdot \mathrm{K}_{1}=$ normal $\mathrm{K}$ supply; $\mathrm{K}_{2}=$ $\mathrm{K}$-deficiency stress. Different lowercase letters in the same column indicate significant differences at $P \leq 0.05$.

Table 5. Root vigor in different tobacco varieties under two K application treatments $\left(\mathrm{mg} \cdot \mathrm{g}^{-1} \cdot \mathrm{h}^{-1}\right)$.

\begin{tabular}{lccc}
\hline Variety & $\mathrm{K}_{1}$ & $\mathrm{~K}_{2}$ & $\triangle \mathrm{K}\left(\mathrm{K}_{1}-\mathrm{K}_{2}\right)$ \\
\hline ND202 & $1.89 \mathrm{a}$ & $1.56 \mathrm{a}$ & $0.33 \mathrm{~b}$ \\
NC89 & $1.55 \mathrm{~b}$ & $1.03 \mathrm{~b}$ & $0.52 \mathrm{a}$ \\
K326 & $1.51 \mathrm{~b}$ & $1.01 \mathrm{~b}$ & $0.50 \mathrm{a}$ \\
\hline
\end{tabular}

Different lowercase letters in the same column indicate significant differences at $P \leq 0.05$.

$\mathrm{K}_{1}=$ normal $\mathrm{K}$ supply; $\mathrm{K}_{2}=\mathrm{K}$-deficiency stress. relative to the other two varieties. Stress-

two varieties. This result indicated that ND202 presented the most intense stress response under K-deficiency stress, to reduce the accumulation of ROS in its cells and enhance the stress resistance of root cells.

\section{Discussion}

There are significant differences on $\mathrm{K}$ uptake, utilization, and accumulation in various species and different varieties of the same species ( $\mathrm{Lu}$ et al., 2003). The present study was conducted to interpret the differences in soil $\mathrm{K}$ activation and utilization by roots among various tobacco varieties under different conditions. Our results revealed that K-deficiency stress could cause higher levels of organic acid secretion in tobacco roots, which indicated stress caused by $\mathrm{K}$ deficiency led to the adaptation in plants for activating slowly available $\mathrm{K}$ to increase $\mathrm{K}$ absorption (Trejo-Téllez et al., 2010). Furthermore, under both $\mathrm{K}$ supply conditions, the amount of organic acids and the available $\mathrm{K}$ content in the rhizosphere soil were higher in ND202 than in K326 and NC89. These results suggested high-K variety secreted many organic acids into the soil, thereby inducing the release of large quantities of slowly available $\mathrm{K}$, accelerating its transformation into available $\mathrm{K}$ (Ikka et al., 2013). This finding indicated that the organic acids played an important role in transforming different $\mathrm{K}$ forms in the rhizosphere soil. Tobacco varieties capable of secreting higher levels of organic acids through the roots could adapt better to K-deficiency stress and absorb greater amounts of $\mathrm{K}$ from soil.

Plant roots discharge hydrogen ions and organic ligands through ion channels, which are then adsorbed on the root epidermis (Breygina et al., 2010; Dai and Chen, 2005). Organic acids in root exudates can dissolve and transform certain insoluble minerals via acidification, ligand exchange, and reduction, thus allowing nutrient release and thereby improving the bioavailability of nutrients (Guo et al., 2007). The present study demonstrated that the activation of soil organic $\mathrm{K}$ by organic acids was a result of acidification combined with complex formation, which was an important mechanism whereby tobacco roots improved the soil available K content under K-deficiency condition. In addition, our study confirmed that the acidification and complexation of organic acids were synergistic, and both played a vital role in improving available $\mathrm{K}$ content in the rhizosphere soil.

Table 6. Stress-resistant enzymes activities in different tobacco varieties under two $\mathrm{K}$ application treatments.

\begin{tabular}{|c|c|c|c|c|c|c|c|c|c|}
\hline \multirow[b]{2}{*}{ Variety } & \multicolumn{3}{|c|}{ SOD $\left(U \cdot g^{-1} F W\right)$} & \multicolumn{3}{|c|}{ POD $\left(\mathrm{U} \cdot \mathrm{g}^{-1} \mathrm{FW}\right)$} & \multicolumn{3}{|c|}{$\operatorname{CAT}\left(\mathrm{U} \cdot \mathrm{g}^{-1} \mathrm{FW}\right)$} \\
\hline & $\mathrm{K}_{1}$ & $\mathrm{~K}_{2}$ & $\triangle \mathrm{K}\left(\mathrm{K}_{1}-\mathrm{K}_{2}\right)$ & $\mathrm{K}_{1}$ & $\mathrm{~K}_{2}$ & $\triangle \mathrm{K}\left(\mathrm{K}_{1}-\mathrm{K}_{2}\right)$ & $\mathrm{K}_{1}$ & $\mathrm{~K}_{2}$ & $\triangle \mathrm{K}\left(\mathrm{K}_{1}-\mathrm{K}_{2}\right)$ \\
\hline ND202 & $223.32 \mathrm{c}$ & $289.16 \mathrm{~b}$ & $65.84 \mathrm{a}$ & $17.92 \mathrm{~b}$ & $26.08 \mathrm{a}$ & $8.17 \mathrm{a}$ & $3.43 \mathrm{a}$ & $6.80 \mathrm{a}$ & $3.37 \mathrm{a}$ \\
\hline K326 & $308.90 \mathrm{~b}$ & $355.88 \mathrm{a}$ & $46.99 \mathrm{~b}$ & $23.30 \mathrm{a}$ & $28.02 \mathrm{a}$ & $4.72 \mathrm{~b}$ & $2.95 \mathrm{~b}$ & $3.62 \mathrm{~b}$ & $0.67 \mathrm{~b}$ \\
\hline NC89 & $315.96 \mathrm{a}$ & $366.85 \mathrm{a}$ & $50.90 \mathrm{~b}$ & $21.88 \mathrm{a}$ & $25.82 \mathrm{a}$ & $3.93 \mathrm{~b}$ & $3.27 \mathrm{~b}$ & $3.90 \mathrm{~b}$ & $0.64 \mathrm{~b}$ \\
\hline
\end{tabular}

Different lowercase letters in the same column indicate significant differences at $P \leq 0.05$.

$\mathrm{CAT}=$ catalase $; \mathrm{FW}=$ fresh weight; $\mathrm{K}_{1}=$ normal $\mathrm{K}$ supply; $\mathrm{K}_{2}=\mathrm{K}$-deficiency stress; $\mathrm{POD}=$ peroxidase; $\mathrm{SOD}=$ superoxide dismutase.
Root morphology and physiological characteristics largely determine the ability of plants to absorb $\mathrm{K}$ from soil (Giehl et al., 2014). In the present study, it was found that ND202 displayed a smaller reduction of root vigor but a greater increase in stress-resistant enzyme activities under K-deficiency stress. K-deficiency stress had a smaller negative impact on ND202 than on K326 and NC89, which was one of the reasons that high-K variety exhibited higher contents of exuded organic acids and activated soil available $\mathrm{K}$ in the rhizosphere soil (Chou and Zeng, 2010; Xue et al., 2016).

In summary, the coexistence of acidification and complex formation significantly increased the soil available K content. Furthermore, tobacco plants, which displayed relatively high root vigor and activities of stress-resistant enzymes, could maintain relatively high exudation of organic acids and activate a greater amount of slowly available $\mathrm{K}$ in the rhizosphere soil under K-deficiency treatment. Thus, screening of varieties with high contents of organic acids in root exudates is a possible regulatory pathway for improving $\mathrm{K}$ content in tobacco leaves.

\section{Literature Cited}

Ae, N., J. Arihara, K. Okada, T. Yoshiham, and C. Johansen. 1990. Phosphorus uptake by pigeon pea and its role in cropping system of the India subcontinent. Science 248(4954):477-480.

Breygina, M.A., A.V. Smirnova, M.V. Maslennikov, N.P. Matveeva, and I.P. Yermakov. 2010. Effects of anion channel blockers NPPB and DIDS on tobacco pollen tube growth and its mitochondria state. Cell Tissue Biol. 52(4): 289-296.

Carvalhais, L.C., P.G. Dennis, D. Fedoseyenko, M.R. Hajirezaei, R. Borriss, and N. von Wirén. 2011. Root exudation of sugars, amino acids, and organic acids by maize as affected by nitrogen, phosphorus, potassium, and iron deficiency. J. Plant Nutr. Soil Sci. 174(1):3-11.

Chen, L.H., X.M. Yang, W. Raza, J.H. Li, Y.X. Liu, M.H. Qiu, F.G. Zheng, and Q.R. Shen. 2011. Trichoderma harzianum SQR-T037 rapidly degrades allelochemicals in rhizospheres of continuously cropped cucumbers. Appl. Microbiol. Biotechnol. 89(5):1653-1663.

Chiang, P.N., M.K. Wang, C.Y. Chiu, and S.Y. Chou. 2006. Effects of cadmium amendments on low-molecular weight organic acid exudates in rhizosphere soils of tobacco and sunflower. Environ. Toxicol. 21(5):479-488.

Chou, C.H. and R.S. Zeng. 2010. Role of allelopathy in sustainable agriculture: Use of allelochemicals as naturally occurring bioagrochemicals. Allelopathy J. 25(1):3-16.

Cong, R.H., X.K. Li, J.W. Lu, Y.P. Ma, Z.W. Liao, and C.C. Jiang. 2009. Effect of low-molecularwater organic acids on transformation of potassium in red soil and yellow cinnamon soil in South China. Turang Xuebao 46(3):532-536.

Cui, J.Y., L. Ren, J.G. Wang, and F.S. Zhang. 2002. Effect of organic acids on mobilization of $\mathrm{K}$ from K-bearing minerals and stochastic simulation of dynamic $\mathrm{K}$ release. Turang Xuebao 39(3):341-350.

Cui, M.Y., Y.C. Lin, Y.G. Zu, T. Efferth, D.W. Li, and Z.H. Tang. 2015. Ethylene increases accumulation of compatible solutes and decreases oxidative stress to improve plant tolerance to 
water stress in Arabidopsis. J. Plant Biol. 58(3): 193-201.

Dai, S.X. and S.L. Chen. 2005. Research review on root ion channels of plants. J. Beijing For. Univ. 27(3):98-103.

Feldman, I.J. 1984. Regulation of root development. Annu. Rev. Plant Physiol. 35(1):223242.

Furoc-Paelmo, R., R.G. Visco, W.M. Carandang, A.S.A. Castillo, and R.V.O. Cruz. 2012. Relationship of Jatropha curcas L. growth parameters with soil and microclimatic factors in varying short rotation-based agroforestry system. Philipp. J. Crop Sci. 37(3):76-87.

Gandner, W.K., D.A. Barber, and D.G. Parberry. 1983. The acquisition of phosphorus by Lupinus albus L.III. The probable mechanism by which phosphorus movement in the soil/root interface is enhanced. Plant Soil 70(1):107-124.

Garcia-Limones, C., A. Hervas, J.A. Navas-Cortes, R.M. Jimenez-Diaz, and M. Tena. 2002. Induction of an antioxidant enzyme system and other oxidative stress markers associated with compatible and incompatible interactions between chickpea (Cicer arietinum L.) and Fusarium oxysporum f. sp. ciceris. Physiol. Mol. Plant Pathol. 61(6):325-337.

Giehl, R.F.H., B.D. Gruber, and N. Von Wirén. 2014. It's time to make changes: Modulation of root system architecture by nutrient signals. J. Expt. Bot. 65(3):769-778.

Guo, L.Z., F.S. Zhang, and C.J. Li. 2002. Effects of decapitation on growth, uptake and distribution of potassium in tobacco. Chin. J. Appl. Chem. 13(7):819-822.

Guo, T.R., G.P. Zhang, M.X. Zhou, F.B. Wu, and J.X. Chen. 2007. Influence of aluminum and cadmium stresses on mineral nutrition and root exudates in two barley cultivars. Pedosphere 17(4):505-512.

Haichar, F.E.Z., C. Santaella, T. Heulin, and W. Achouak. 2014. Root exudates mediated interactions belowground. Soil Biol. Biochem. 77:69-80.

Hao, W.Y., L.X. Ren, W. Ran, and Q.R. Shen. 2010. Alleopathic effects of root exudates from watermelon and rice plants on Fusarium oxysporum f.sp. niveum. Plant Soil 336(1-2):485497.

He, Y.C., C.L. Ma, J.H. Xu, and L. Zhou. 2011. A high-throughput screening strategy for nitrilehydrolyzing enzymes based on ferric hydroxamate spectrophotometry. Appl. Microbiol. Biotechnol. 89(3):817-823.

Hoffland, E., G.R. Fmdenegg, and J.A. Nelmans. 1989. Solubilization of rock phosphate by rape. I. Evaluation of the role of the nutrient uptake pattern. Plant Soil 113(2):155-160.

Hoffland, E., C.Z. Wei, and M. Wissuwa. 2006. Organic anion exudation by lowland rice (Oryza sativa L.) at zinc and phosphorus deficiency. Plant Soil 283(1-2):155-162.

Ikka, T., T. Ogawa, D. Li, S. Hiradate, and A. Morita. 2013. Effect of aluminum on metabolism of organic acids and chemical forms of aluminum in root tips of Eucalyptus camaldulensis Dehnh. Phytochemistry 94(10):142147.
Jiang, L., R.Z. Yang, Y.F. Lu, S.Q. Cao, L.K. Ci, and J.J. Zhang. 2012. $\beta$-aminobutyric acidmediated tobacco tolerance to potassium deficiency. Russ. J. Plant Physiol. 59(6):781-787.

Ling, N., Q.W. Huang, S.W. Guo, and Q.R. Shen. 2011. Paenibacillus polymyxa SQR-21 systemically affects root exudates of watermelon to decrease the conidial germination of Fusarium oxysporumf sp. niveum. Plant Soil 341(12):485-493.

Lipton, D.S., R.W. Blanchar, and D.G. Blevins. 1987. Citrate, malate, and succinate concentration in exudates from P-sufficient and Pstressed Medicago sativa $\mathrm{L}$. seedlings. Plant Physiol. 85(2):315-317.

Liu, B.L., Z.B. Fan, Z.Q. Liu, X.H. Qiu, and Y.H. Jiang. 2018. Comparison of phytochemical and antioxidant activities in micropropagated and seed-derived Salvia miltiorrhiza plants. HortScience 53:1038-1044.

Lu, G.Q., M.S. George, and W. Zhou. 2003. Genotypic variation of sweetpotatoes grown under low potassium stress. J. Plant Nutr. 26(4): 745-756.

Luo, J.X., H.Q. Xiao, J.W. Peng, and W.C. Zhou. 2000. Effects of potassium application methods on potassium supply capability of soil and potassium accumulation in flue-cured tobacco. J. Hunan Agr. Univ. Nat. Sci. 26(5):352-354.

Melo, V.D.F., G.F. Corrêa, A.N. Ribeiro, and P.A. Maschio. 2005. Kinetics of potassium and magnesium release from clay minerals of soils in the Triângulo Mineiro region, Minas Gerais state, Brazil. Rev. Bras. Ciênc. Solo 29(4):533545.

Meng, Z.J., L.L. Tong, L.L. Gao, S.C. Yan, and Y.F. Lu. 2017. Activities of some defense proteins associated with age or plant family in larch needles of Larix olgensis and L. kaempferi $\times$ L. gmelinii. J. For. Res. 28(1):63-69.

Mohan, A., M. Girdhar, H. Rehman, A. Kumar, S. Saggu, and A.A. Ansari. 2015. Metal accumulation capability of weeds and their utilization in phytoremediation technology. Phytoremediation 2:343-357.

Qian, X.G., J. Yang, and R.H. Zhu. 1998. Tobacco nutrition and fertilizer, p. 1-10. Guizhou Science and Technology Press, Guiyang.

Qu, C.X., C. Liu, X.L. Gong, C.X. Li, M.M. Hong, L. Wang, and F.S. Hong. 2012. Impairment of maize seeding photosynthesis caused by a combination of potassium deficifency and salt stress. Environ. Expt. Bot. 75:134-141.

Ryssov-Nielson, H. 1975. Measurement of the inhibition of respiration in activated sludge by a modified determination of the TTCdehydrogenase activity. Water Res. 9(12): 1179-1185.

Shi, S.J., A.E. Richardson, M. O'Callaghan, K.M. DeAngelis, E.E. Jones, A. Stewart, M.K Firestone, and L.M. Condron. 2011. Effects of selected root exudate components on soil bacterial communities. FEMS Microbiol. Ecol. 77(3):600-610.

Sison, M.L.Q., J.P.V. Magbanua, E.C. Bugante, F.G. Torres, F.R.P. Nayve, V.P. Migo, and W.L. Fernandez. 2010. Agro-recycling of distillery effluent as liquid organic fertilizer for sugarcane. Philipp. J. Crop Sci. 35(3):1-8.
Trejo-Téllez, L.I., R. Stenzel, F.C. Gomez-Merino, and J.M. Schmitt. 2010. Transgenic tobacco plants overexpressing pyruvate phosphate dikinase increase exudation of organic acids and decrease accumulation of aluminum in the roots. Plant Soil 326(1-2):187-198.

Wang, X., H.T. Liang, T. Liu, L. Li, B. Zhu, C.H. Zhang, L.L. Liu, and J.J. Yu. 2014. Effects of potassium fertilizer rate and potassium application methods on quality of middle tobacco leaves. Hunan Nongye Kexue 10:28-31.

Williams, C.H. and J.R. Twine. 1960. Flame photometric method for sodium, potassium and calcium, p. 3-5. In: K. Peach and M.V. Tacey (eds.). Modern methods of plant analysis. Vol. 5. Springer-Verlag, Berlin.

Wu, H.S., W. Raza, D.Y. Liu, C.L. Wu, Z.S. Mao, Y.C. Xu, and Q.R. Shen. 2008. Allelopathic impact of artificially applied coumarin on Fusarium oxysporum f.sp. niveum. World J. Microb. Biot. 24(8):1297-1304.

Wu, Y.H., L.X. Xue, Z.C. Xu, H.F. Shao, L. Jin, W.X. Huang, and C.K. Liu. 2013. Combined effects of root cutting, auxin application, and potassium fertilizer on growth, sugar: Nicotine ratio, and organic potassium index of fluecured tobacco. Acta Ecol. Sin. 33(18):56865695.

Xue, G., L.M. Lu, T.Z. Yang, X.H. Li, X.X. Xing, and S.X. Xu. 2016. Enhanced tolerance to low$\mathrm{K}^{+}$stress in tobacco plants, that ectopically express the CBL-interacting protein kinase CIPK23 gene. Czech J. Genet. Plant Breed. 52(2):77-82.

Yang, T.Z. and Y.F. Peng. 2006. Potassium accumulation characteristics of rich-potassium genotypic flue-cured tobacco. Zhiwu Yingyang Yu Feiliao Xuebao 12(5):750-753.

Yu, H.Y., H.B. Liang, G.M. Shen, D.A. Sampietro, and X.X. Gao. 2014. Effects of allelochemicals from tobacco root exudates on seed germination and seedling growth of tobacco. Allelopathy J. 33(1):107-120.

Zeng, F.R., S. Chen, Y. Miao, F.B. Wu, and G.P. Zhang. 2008. Changes of organic acid exudation and rhizosphere $\mathrm{pH}$ in rice plants under chromium stress. Environ. Pollut. 155(2):284 289.

Zhang, F.G., Z. Zhu, X.M. Yang, W. Ran, and Q.R. Shen. 2013. Trichoderma harzianum T-E5 significantly affects cucumber root exudates and fungal community in the cucumber rhizosphere. Appl. Soil Ecol. 72(5):41-48.

Zhang, X., J.W. Mao, W.H. Zhai, L.J. Yang, F.X. Li, M. Xu, and G.P. Li. 2014. Effects of different potassium fertilizer types and dressing depths on yield, quality and nutrient uptake of tobacco. Chin. Tob. Sci. 35(2):69-73.

Zhou, J.H., Y.P. Li, H.Q. Yang, Y. Wang, Y. Shao, Z.M. Guo, L.S. Zhu, and W.G. Ma. 2005. Activated effect of root secretions in the different genotype tobacco to difficult dissolving phosphorus and potassium. J. Hunan Agr. Univ. Nat. Sci. 31(3):276-280.

Zörb, C., M. Senbayram, and E. Peiter. 2014. Potassium in agriculture-status and perspectives. J. Plant Physiol. 171(9):656-669. 